\title{
New prognostic factors in resectable non-small cell lung cancer
}

\author{
E F Smit, H J M Groen, T A W Splinter, T Ebels, P E Postmus
}

Patients presenting with early stage non-small cell lung cancer (NSCLC) are commonly thought to have a favourable prognosis after resection. However, patients with pathological stage I disease have, in fact, a $35-50 \%$ relapse rate at five years, ${ }^{1-3}$ and for pathological stage II the relapse rate is $61 \%{ }^{4}$ Little is known of the factors that account for this poor outcome. Sorensen ${ }^{5}$ concluded from multivariate analysis of five studies which included over 2000 patients with stage I and II NSCLC that stage of disease (size of the primary tumour and lymph node status) and performance status were the only consistent significant prognostic factors. A similar conclusion was reached by Buccheri et al after a literature review. ${ }^{6}$ In both studies other variables analysed, such as histopathological features and traditional laboratory tests, gave conflicting results.

If we were able to identify biologically more aggressive localised NSCLC tumours, additional treatments could be considered. New diagnostic tools from immunology and molecular biology have been proposed for this purpose. In recent years several studies have been published that have retrospectively evaluated putative tumour markers. In this paper we have reviewed the current evidence for the existence of prognostic factors other than stage of disease and performance status in resectable NSCLC.

University Hospital

Groningen,

Groningen,

PO Box 30.001,

9700 RB Groningen,

The Netherlands

Department of Internal Medicine,

University Hospital

Dijkzicht, Rotterdam

T A W Splinter

Department of

Pulmonary Diseases,

University Hospital

Free University,

Amsterdam,

The Netherlands

P E Postmus

Correspondence to: Dr E F Smit.

Received 7 April 1995 Returned to authors 4 July 1995

Revised version received

18 August 1995

18 August 1995

12 December 1995 ment of DNA ploidy and percentage of tumour cells in the $S$ phase (the period in the cell cycle in which DNA replication takes place, fig 1). Since 1987 nine studies ${ }^{7-15}$ have demonstrated an inverse relationship between aneuploidy (abnormal DNA content) and probability of long term survival in resected NSCLC. In two studies, ${ }^{1115}$ including one in which DNA ploidy was not significantly correlated to survival, ${ }^{11}$ patients with a larger fraction of tumour cells in the $S$ phase had a worse prognosis than those with a low fraction. A large number of tumour cells is needed for flow cytometry so this analysis can only be used in resected specimens. In recent years components of cell cycle control mechanisms have been elucidated at the molecular level. Ultimately, the presence or absence of such mechanisms determines the number of cells in the $S$ phase. It has now become possible to evaluate some of the components of cell cycle control in smaller numbers of tumour cells such as in biopsy material.

\section{p53 ABNORMALITIES}

The most extensively studied protein in cell cycle control is the p53 tumour suppressor gene product (fig 2). p53 is a cellular $53 \mathrm{kD}$ nuclear phosphoprotein discovered in the late 1970 s which has subsequently been shown to perform a myriad of cellular functions. It acts as a transcription factor for a number of genes containing the p53 binding site, thereby controlling the cell cycle at the $G_{1} / S$ checkpoint (fig 3), as well as DNA repair, differentiation, neoangiogenesis and apoptosis. ${ }^{16-22}$

Mutations in the gene encoding for $\mathrm{p} 53$ lead to loss of function of the protein, and the mutated gene then acts as a dominant oncogene. It is one of the earliest (but not obligatory) events in malignant transformation in the lung. ${ }^{23-26}$ The most common mutation in lung cancer, which occurs in over $50 \%$ of patients with NSCLC, is a mis-sense mutation - that is, an exchange of one base pair for another in exons $5-8^{23}$ which affects amino acids in the DNA binding region close to the proteinDNA interface. ${ }^{2027}$ Wild type (non-mutated) p53 is not detectable by routine immunohistochemistry due to its short half life. Missense mutations increase the half life and quantity of the p53 protein, allowing detection by immunohistochemistry. ${ }^{28}$ Thus, identification of $\mathrm{p} 53$ protein $(\mathrm{p} 53+)$ in tissue samples implies the activity of the oncogene.
DNA synthesis and mitosis

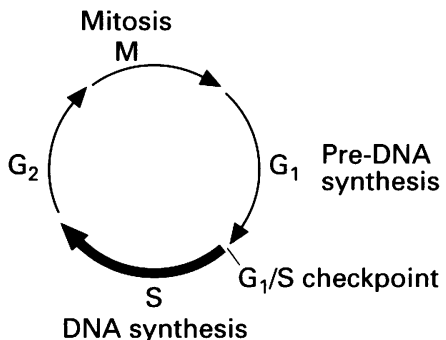

Figure 1 The cell cycle. 


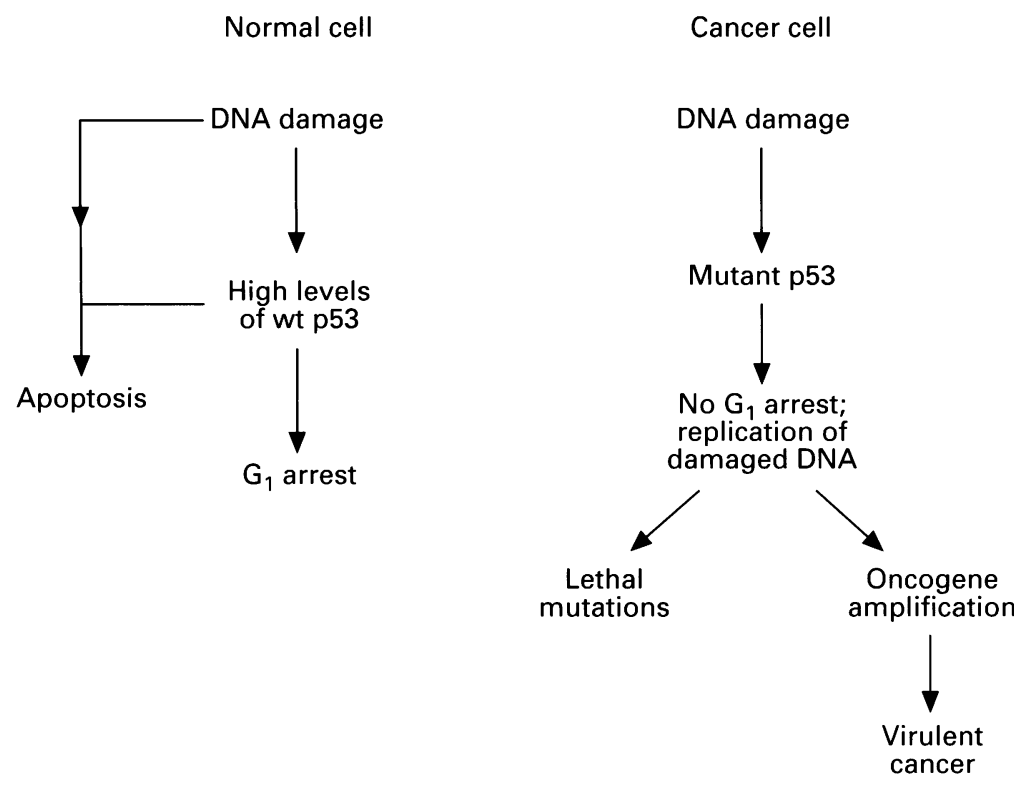

Figure 2 Simplified model to explain how p53 mutations can lead to more virulent cancer. Upon DNA damage normal cells (left) can either die by the apoptotic pathway (programmed cell death) or because rising nuclear levels of wild type (non-mutated) p53 (wt $p 53$ ) cause $G_{1}$ arrest. In cancer cells harbouring a mutant $p 53$ no $G_{1}$ arrest occurs after DNA damage and a more virulent cancer develops by amplification of oncogenes.

Several reports are now available which have retrospectively analysed the influence of p53 mutations on survival in patients with early stage NSCLC (table 1). ${ }^{29-34}$ In all but the smallest study ${ }^{31}$ p53 abnormality was a significant independent predictor of death after both multivariate and univariate analysis. In the largest series, ${ }^{34}$ comprising 271 patients with stage I disease, actual five year survival of the 104 p53 + patients was $53 \%$ compared with $68 \%$ for patients without staining for p53 (p53-) $(\mathrm{p}<0.01)$.

When interpreting data on $\mathrm{p} 53$ abnormalities and the survival of patients with NSCLC, several points have to be kept in mind. Firstly, many reports are older series which do not include present day staging procedures so many of the patients may have been understaged, explaining the rather low median survival times in the p53 - patients. However, abnormality of $\mathrm{p} 53$ remained a negative prognostic factor in the study by Harpole et $a l^{34}$ in which actual survival was $68 \%$ at five years. Secondly, p53 abnormalities can be detected with several different techniques including direct sequencing, single strand conformation polymorphism, and immunohistochemistry, and results differ according to the method used.

Table 1 p53 gene abnormality and survival in patients with stage I and II NSCLC

\begin{tabular}{lcllll}
\hline Author & No. of patients & Method & \multicolumn{2}{l}{ Median survival (months) } & \multirow{2}{*}{ p value } \\
\cline { 4 - 5 } & & & $p 53+(n)$ & $p 53-(n)$ & \\
\hline Quinlan $^{29}$ & 114 & IHC & $23(49)$ & $37(65)$ & $<0.001$ \\
Horio $^{30}$ & 48 & PCR-SSCP & $25(23)$ & NR $(25)$ & $<0.01$ \\
Passlick $^{31}$ & 34 & IHC & NR $(18)$ & $29(16)$ & $<0.005$ \\
Xu $^{32}$ & 101 & IHC & $18(38)$ & $36(63)$ & 0.002 \\
Ebina $^{33}$ & 63 & IHC & NS (11) & NS (52) & $0.002^{*}$ \\
Harpole $^{34}$ & 271 & IHC & $76(104)$ & NR $(167)$ & $<0.01$ \\
\hline
\end{tabular}

IHC = immunohistochemistry; PCR-SSCP = polymerase chain reaction-single strand conformation polymorphism; $\mathrm{NR}=$ not reached; $\mathrm{NS}=$ not stated.

* Survival p53+(>10\%) <p53-(0-10\%).

Significance of difference between pairs of Kaplan-Meier curves was calculated using the MantelHaenszel procedure.

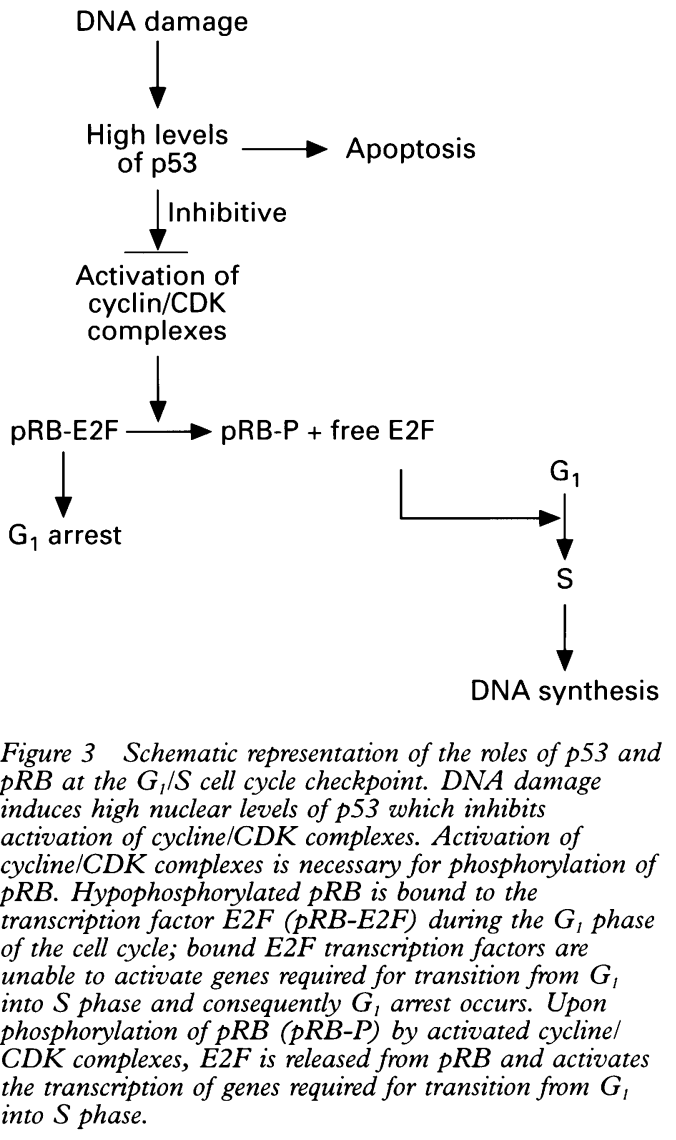

Immunohistochemical analysis of p53 abnormalities in 74 patients with resected NSCLC revealed a significant survival advantage for $\mathrm{p} 53$ - patients $(\mathrm{p}<0.01) .{ }^{35}$ However, when single strand conformation polymorphism and DNA sequencing were performed on the same tumours, no such difference could be found. The concordance between a p53 abnormality detected by immunohistochemistry and single strand conformation polymorphism was only $65 \%$. Several explanations have been put forward for this finding ${ }^{36}$ and, from another study, it was concluded that immunohistochemistry is a sensitive but not specific method for detection of p53 mutations. ${ }^{37}$ Thirdly, the number of cells harbouring a p53 abnormality may be important. Ebina et $a l^{33}$ found no difference in survival in patients whose tumours contained less than $10 \% \mathrm{p} 53$ + tumour cells and there was a significant association with adverse survival only if more than $10 \%$ of tumour cells were positive.

\section{pRB GENE ABNORMALITIES}

Another protein which is implicated at the $G_{1} /$ $S$ cell cycle checkpoint is the retinoblastoma susceptibility gene product $(\mathrm{pRB}) .^{21} \mathrm{pRB}$ appears to act downstream of p53 in response to DNA damage (fig 3). ${ }^{38}$ Data from mice mutant for both genes exhibited, amongst other abnormalities, an increased incidence of bronchial hyperplasia. ${ }^{39}$ Mutations in pRB can be analysed by immunohistochemistry because abnormal $\mathrm{pRB}$ does not stain. $\mathrm{Xu}$ et $a l^{32}$ analysed the influence of $\mathrm{pRB}$ mutations in 101 patients 


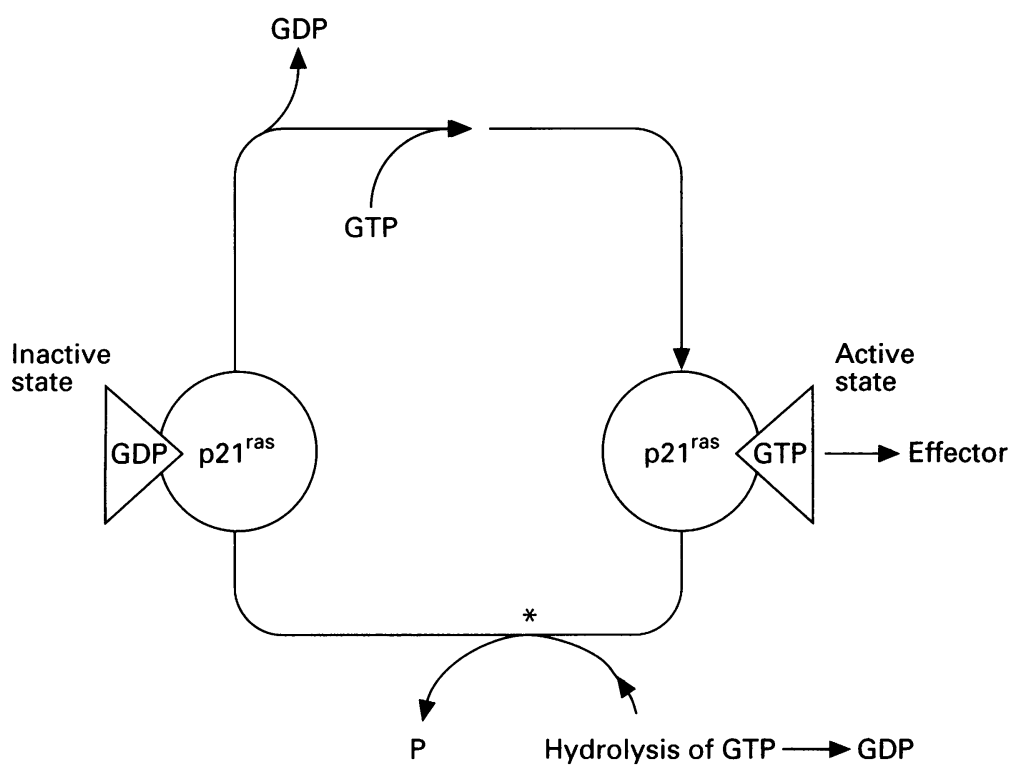

Figure 4 Schematic view of the inactive form of $p 21^{\text {ras }}$ protein binding guanidine diphosphate (GDP) while the active form of $p 21^{\text {ras }}$ binds guanidine triphosphate (GTP). Hydrolysis of GTP by ras proteins or GAP switches $p 21^{\text {ras }}$ to the inactive state. Blocking of the switch $\left(^{*}\right)$ by point mutations transforms $p 21^{\text {ras }}$ into a perpetually active state (ras oncogenes).

with resected stage I and II NSCLC. After a median follow up of more than five years, patients with negative staining for $\mathrm{pRB}$ (mutation) had a median survival of 18 months compared with 32 months for patients with $\mathrm{pRB}+$ tumours $(\mathrm{p}<0 \cdot 05)$. Although 54 patients with stage I disease and pRB - tumours had a similar survival to those with $\mathrm{pRB}+$ tumours (median 22 versus 32 months), for 47 patients with stage II disease the figures were 15 months $(\mathrm{pRB}-)$ versus 31 months $(\mathrm{pRB}+)(\mathrm{p}<0.005)$.

ras MUTATIONS

The three ras genes (H-ras, K-ras and $\mathrm{N}$ ras) are regulatory guanine triphosphate (GTP) binding proteins. ${ }^{40}$ They encode for a $21 \mathrm{kD}$ inner membrane bound protein ( $\left.121^{\text {ras }}\right)$ with high homology (sharing biochemical and structural properties) to $G$ proteins, suggesting a role in signal transduction pathways. $\mathrm{p} 21^{\text {ras }}$ exists in two states: the "active" state in which GTP is bound to the protein, and the "inactive" state in which GTP is hydrolysed to GDP, either by ras proteins themselves or by enhancement of intrinsic rasGTPase activity by GAP (GTPase activating protein). Ras proteins can be turned

Table 2 Ras gene mutations and survival in patients with stage I and II NSCLC

\begin{tabular}{|c|c|c|c|c|}
\hline Author & No. of patients & Method & Survival & $p$ value \\
\hline $\begin{array}{l}\text { Slebos }^{42} \\
\text { Mitsudomi }^{48} \\
\text { Miyamoto }^{7} \\
\text { Harada }^{49} \\
\text { Sugio } \\
\text { Rosell }^{47} \\
\text { Kern }^{45}\end{array}$ & $\begin{array}{l}66^{1} \\
21^{2} \\
44^{3} \\
49 \\
76^{4} \\
66 \\
44^{6}\end{array}$ & $\begin{array}{l}\text { PCR } \\
\text { PCR } \\
\text { IHC } \\
\text { IHC } \\
\text { PCR } \\
\text { PCR } \\
\text { PCR }\end{array}$ & $\begin{array}{l}\text { K-ras }+<\text { K-ras }- \\
\text { K-ras }+<\text { K-ras - } \\
\text { ras p21+<ras p21- } \\
\text { ras p21+<ras p21- } \\
\text { ras }+<\text { ras -5 } \\
\text { K-ras }+<\text { K-ras - } \\
\text { K-ras }+<\text { K-ras - }\end{array}$ & $\begin{array}{l}0.002 \\
0.002 \\
<0.05 \\
<0.05 \\
0.02 \\
0.001 \\
0.06\end{array}$ \\
\hline
\end{tabular}

IHC = immunohistochemistry; $\mathrm{PCR}=$ polymerase chain reaction.

'Adenocarcinomas.

Cell lines established from patients after curative surgery $(n=19)$ or radiotherapy with curative intent $(n=2)$.

${ }^{3}$ intent $(n=2)$.

${ }_{4}$ Patients underwent curative surgery, stage not provided.
76 treated with curative surgery, including 61 stage I and II.

5 Any ras mutation, survival analysis includes node negative patients $(n=57)$.

"Adenocarcinomas, including eight stage IV patients.
"Adion into oncogenes by a single point mutation, most common in codon 12, involving the GTP binding region (mutational activation). Such mutations prevent ras proteins returning from the "active" to the "inactive" state leading to malignant transformation ${ }^{41}$ (fig 4). Point mutations can specifically be detected by oligonucleotide hybridisation techniques with incorporation of the polymerase chain reaction (PCR) in small tissue samples. ${ }^{42}$ Enhanced expression - that is, the process leading from gene transcription (mRNA synthesis) to protein synthesis - of the ras genes can also lead to malignant transformation. ${ }^{43} \mathrm{~A}$ monoclonal antibody raised against $\mathrm{p} 21^{\text {ras }}$ is available, allowing immunohistochemical detection of $\mathrm{p} 21^{\text {ras }}$. It is not known how $\mathrm{p} 21^{\text {ras }}$ expression as assessed by immunohistochemistry correlates with K-ras mutations.

Mutational activation of ras genes has been found in a number of human malignancies including lung cancer. Most ras mutations in NSCLC are found in adenocarcinomas; Rodenhuis et $a l^{41}$ reported a $30 \%$ prevalence of $\mathrm{K}$-ras mutations in codon 12 in adenocarcinoma. However, in a recent report ${ }^{44}$ in which a more sensitive PCR based assay was used, it was shown that the prevalence of K-ras codon 12 mutations in the same samples was underestimated and was found to be about $50 \%$. Enhanced expression of $\mathrm{p} 21^{\mathrm{ras}}$ occurs in over $50 \%$ of all histological types of NSCLC.

The effect of ras gene mutations on survival in patients with stage I and II NSCLC is shown in table 2 . Slebos et $a l^{42}$ retrospectively analysed the clinical outcome of 69 patients with resected adenocarcinoma of the lung with regard to $\mathrm{K}$-ras codon 12 point mutation. The analysis was limited to patients suffering from adenocarcinoma only, since they previously found that K-ras mutations were uncommon in other types of NSCLC. Twelve of 19 patients with samples showing a K-ras mutation died during a median follow up period of 36 months, compared with 22 of 50 without a mutation $(\mathrm{p}<0.001)$. K-ras point mutation was the single most important prognostic factor in patients with a mutation after adjustment for stage of disease. In a similar group of patients with adenocarcinoma Kern et $a l^{45}$ found a $16 \%$ incidence of codon $12 \mathrm{~K}$-ras mutations. In a multivariate model, controlling for stage and age, K-ras codon 12 mutation was a poor prognostic factor of borderline significance $(p=0.06)$. In a subset of 57 patients with adenocarcinoma without lymph node metastases at thoractomy described by Sugio et al, ${ }^{46}$ nine had a point mutation in one of three ras genes and the five year survival rate of these patients was significantly lower $(p<0.02)$ than for those without a ras mutation $(53.3 \%$ versus $83.6 \%$ ). Rosell et $a l^{47}$ found K-ras mutations in codons 12,13, and 61 more frequently in patients with squamous cell carcinoma (eight of 38) than with adenocarcinomas (three of 22). Median survival for the group with $K$-ras mutations was 15 months compared with 32.9 months for those without $\mathrm{K}$-ras mutations $(p<0.01)$. When cell lines established from patients with NSCLC treated with curative 
intent are analysed for a ras gene mutation, the latter predicts for adverse survival. ${ }^{48}$

In two studies ${ }^{749} \mathrm{p} 21^{\text {ras }}$ expression analysis by immunohistochemistry yielded somewhat different results. More than $55 \%$ immunoreactivity was found in patients with squamous cell carcinoma and more than $70 \%$ in those with adenocarcinomas. Non-neoplastic cells of the lung also react with this antibody. In both studies, comprising probably the same study population, when strong $\mathrm{p} 21^{\text {ras }}$ immunoreactivity in pathological stage I and II NSCLC was encountered, five year survival was $22 \%$ compared with $74 \%$ for patients without $\mathrm{p} 21^{\text {ras }}$ overexpression $(p<0.05)$. The distribution of tumour histologies was similar between positive and negative patients, but strong staining was associated with more advanced disease.

In conclusion, a K-ras mutation and $\mathrm{p} 21^{\text {ras }}$ overexpression are predictive of shortened survival after curative resection of NSCLC. The prevalence of K-ras mutations is unknown and may rise as assays become more sensitive.

\section{c-erbB-2/neu OVEREXPRESSION}

The c-erbB-2 gene, also known as Her-2, encodes for a $185 \mathrm{kD}$ transmembrane protein $\left(\mathrm{p} 185^{\mathrm{neu}}\right)$ which possesses intrinsic tyrosine kinase activity. The protein has extensive homology to the epidermal growth factor receptor. A ligand for $\mathrm{p} 185^{\text {neu }}$ is not yet identified. In vivo experiments with c-erbB-2/neu transfected NSCLC cells indicate that $\mathrm{p} 185^{\text {neu }}$ overexpression (usually the result from gene amplification - that is, an increased number of gene copies - but occasionally resulting from enhanced transcription of a single gene) enhances the metastatic potential of these cells by promoting the invasion process. ${ }^{50}$ In the normal lung c-erbB-2 is expressed at low levels in ciliated cells lining the respiratory tract, type II pneumocytes and bronchial mucosal glands as measured by immunohistochemistry using a polyclonal antibody. ${ }^{51}$ Amplification of the c-erbB-2 gene is a rare event in primary NSCLC, ${ }^{52}$ but overexpression has been found in all histological types of NSCLC, although it is more common in adenocarcinoma with a frequency of about $30 \% .{ }^{53}$

In other epithelial carcinomas such as breast cancer $\mathrm{p} 185^{\mathrm{neu}}$ overexpression has been associated with higher metastatic potential and adverse clinical outcome, and the relationship between $\mathrm{p} 185^{\text {neu }}$ overexpression and survival in patients with NSCLC has been investigated in four studies. ${ }^{3455154}$

Kern et $a l^{4551}$ were the first to report a diminished survival for patients suffering from adenocarcinoma of the lung with c-erbB-2 overexpression. In their first study, ${ }^{51} 16$ of 26 patients with adenocarcinoma (including nine non-surgical patients) expressed $\mathrm{p} 185^{\text {neu }}$ and mean survival of these patients was $83.7^{\circ}$ weeks compared with 188.5 weeks for the others $(\mathrm{p}<0.01) \cdot \mathrm{p} 185^{\text {neu }}$ expression was the only factor with prognostic value after accounting for the effect of stage of disease on survival in multivariate analysis. For patients with squamous cell carcinoma ( $5 / 14$ positive) $\mathrm{p} 185^{\text {neu }} \mathrm{ex}-$ pression was not associated with a decreased survival in this small sample.

In a second study by the same group ${ }^{45}$ comprising 44 patients with adenocarcinoma, including eight non-surgical patients, 15 had a tumour which expressed p185 $5^{\text {neu }}$. Expression of this protein was associated with a $2 \cdot 4$-fold increase in the patient's relative risk of dying of NSCLC in comparison with those whose tumours did not express p185 $5^{\text {neu }}(\mathrm{p}=0.02)$. Tateishi et al ${ }^{54}$ investigated 203 primary NSCLC specimens (119 adenocarcinoma, 84 squamous cell carcinoma) for expression of $\mathrm{p} 185^{\mathrm{neu}}$. Only two squamous cell carcinomas stained positive with a polyclonal rabbit antic-erbB-2 antibody, while 33 of 99 surgical patients with adenocarcinomas stained positively. The five year survival rate for these patients was $32 \%$ compared with $50 \%$ for patients with negative staining lesions $(\mathrm{p}<0 \cdot 01)$. Harpole et $a \mathrm{l}^{\beta 4}$ observed immunoreactivity with a p185 ${ }^{\text {neu }}$ directed antibody in all major histology types of pathological stage I NSCLC with a frequency of $21 \%$ (58 of 271). Median survival was 47 months for "positive" patients and over 60 months in the others $(p<0 \cdot 002)$. Expression of $p 185^{\text {neu }}$ was an independent risk factor for cancer death in a multivariate model.

COMBINED EFFECTS OF DNA CONTENT, p53,

\section{$\mathrm{RB}$, ras AND c-erbB-2 ABNORMALITIES}

Malignant transformation is a multistep process involving multiple genetic and biochemical abnormalities. Thus, combinations of markers may be more important in defining high risk patients. Two large studies have investigated the effect of a p53 abnormality combined with either c-erbB-2 overexpression ${ }^{34}$ or $\mathrm{pRB}$ mutation $^{32}$ on survival in patients with early stage NSCLC. In the study by Harpole et $a l^{34} \mathrm{c}-$ erbB-2 expression and p53 staining had an additive effect on survival in patients with pathological stage I NSCLC. When either one of these oncogenes was expressed (108 of 271), median survival was not reached by 60 months, whereas when both were expressed (27 of 271) median survival was only 37 months $(\mathrm{p}<0.0005)$. The authors suggested that cerbB-2 and p53 acted independently on tumorigenesis, supported by the fact that Cox proportional regression analysis defined an independent risk of early recurrence and cancer death for both p53 and c-erbB-2, while no covariance for both markers was observed in the study population.

In another study in which data of p53 staining and $\mathrm{pRB}$ staining were combined, similar results were obtained. ${ }^{32}$ Of 101 patients with resected stage I and II NSCLC, those with tumours with the overall "best" pRB and p53 status $(\mathrm{pRB}+/ \mathrm{p} 53-)$ had a median survival time of 46 months, whereas patients with the theoretically "worst" pRB and p53 tumour status $(\mathrm{pRB}-/ \mathrm{p} 53+)$ had a median survival time of 12 months $(p<0.001)$. Multivariate analysis suggested that both $\mathrm{pRB}$ and $\mathrm{p} 53$ status were independent prognostic factors for overall survival. In a Japanese study, ${ }^{20}$ no additive effect 


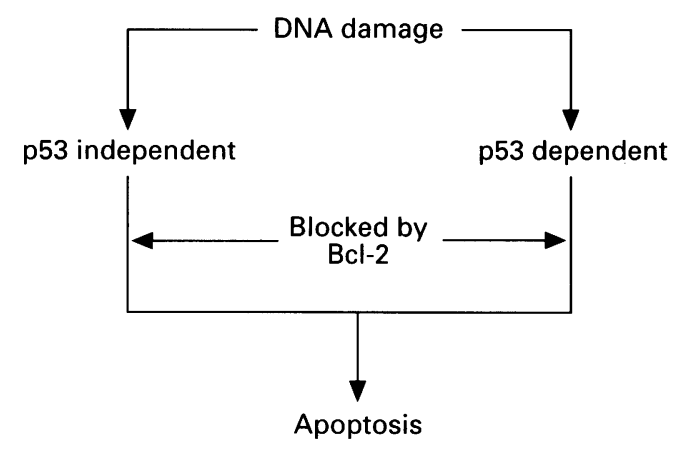

Figure 5 Two ways in which Bcl-2 can inhibit apoptosis or programmed cell death. Following DNA damage p53 dependent and p53 independent apoptotic pathways can be blocked by Bcl-2.

of $3 p$ deletions (involving three putative tumour suppressor genes ${ }^{55}$ ) on p53 staining was observed. In this study there was a significant association between $3 p$ deletions and a p53 mutation.

Ras abnormalities in combination with cerbB-2 expression ${ }^{45}$ or DNA aneuploidy ${ }^{7}$ confer a worse prognosis than either abnormality alone. Of 44 patients with adenocarcinoma, including 36 with pathological stage I and stage II, six tumours harboured both a K-ras mutation and c-erbB- 2 expression with a $4 \cdot 4$-fold increase in relative risk of cancer related death $(p<0.005)$. The influence of each marker was independent in a multivariate model. Survival of these patients was significantly worse than for patients with tumours that contained neither single abnormality, although survival figures were not provided. ${ }^{45}$

Combination of DNA aneuploidy and strong p $21^{\text {ras }}$ expression was observed in 33 of 60 patients with NSCLC of all histological types. These patients had significantly worse survival (five year survival rate $21 \%$ ) than those whose tumours had both diploidy and negative $\mathrm{p} 21^{\text {ras }}$ staining $(n=10$, five year survival rate $100 \%$; $\mathrm{p}<0.001)$. $^{7}$

\section{Bcl-2 EXPRESSION}

Bcl-2 is the acronym for the B cell lymphoma/ leukaemia-2 gene. The protein for which this gene encodes is localised at several subcellar sites and blocks a final common pathway for programmed cell death, also known as apoptosis (fig 5).$^{56}$ Apoptosis is a normal homeostatic mechanism in all tissues with the capacity for self-renewal such as lymphoid tissue and several epithelial tissues. Overproduction of Bcl-2 protein prevents cell death without necessarily affecting proliferation. Pezzella $e t a l^{57}$ evaluated a series of 122 patients with stage I and II NSCLC for Bcl-2 expression by immunohistochemistry. Expression of $\mathrm{Bcl}-2$ was observed in $25 \%(20 / 80)$ of patients with squamous cell carcinoma and $12 \%(5 / 42)$ of those with adenocarcinoma. There was no association between Bcl-2 expression and stage of disease. When the whole patient population was analysed, those with Bcl-2 expression in their tumours had a non-significant difference in five year survival rate $(68 \%)$ compared with
Bcl-2 negative patients (44\%). However, when patients with squamous cell carcinoma were studied separately, the association between Bcl2 expression and survival reached statistical significance $(78 \%$ versus $48 \%$ five year survival, $\mathrm{p}<0.05)$. Walker et $a l^{58}$ reported a higher frequency of Bcl-2 staining in 16 of 27 patients with resected NSCLC. No significant difference in survival was found at two years after resection for patients with tumours which were negative for Bcl-2 compared with those with Bcl-2 positive tumours. In contrast, patients whose tumours had $50-100 \% \mathrm{Bcl}-2$ positive cells $(n=12)$ had a significantly longer survival than those with $0-25 \% \mathrm{Bcl}-2$ positive tumour cells $(n=15, p<0.02)$, At present it is unclear why $\mathrm{Bcl}-2$ expression seems to be associated with less aggressive tumour behaviour in NSCLC. To assess the clinical utility of this marker, a larger series of patients than hitherto reported needs to be investigated. ${ }^{58}$

\section{Carbohydrate antigens}

Factors that are important in cell-cell and cellmatrix adhesion processes include the carbohydrate moieties of glycoproteins and glycolipids. ${ }^{59}$ Aberrant glycosylation of these proteins is a frequent event in human cancers ${ }^{60}$ and is associated with increased metastatic potential of tumour cells. ${ }^{6162}$ The antigenic determinants of $\mathrm{ABH}$ blood group antigens are carbohydrate side chains of glycolipids and glycoproteins. In lung cancer, changes in blood group $\mathrm{ABH}$ antigens are frequent. The tumours lose their mature blood group A and B determinants, and the precursor antigen $\mathrm{H}$ and $\mathrm{H}$-related antigens often increase reciprocally. Lee et a $l^{63}$ examined the presence of blood group A, B and $\mathrm{H}$ in 164 patients with NSCLC tumours resected for cure. Twenty eight patients with blood group type $\mathrm{A}$ or $\mathrm{AB}$ who had primaries negative for blood group antigen $\mathrm{A}$ had a median survival of 15 months, whereas a median survival of 71 months was observed in the 43 patients with the same blood groups who retained expression of blood group antigen $A$ on their tumours $(p<0 \cdot 001)$. Expression of blood group $\mathrm{B}$ or $\mathrm{H}$ on malignant cells did not correlate with survival. Cox regression analysis showed that expression of blood group $\mathrm{A}$ in tumour cells added significantly to overall survival when other known factors such as stage of disease were controlled for. Binding of a monoclonal antibody, designated MIA-15-5, which defines $\mathrm{H} / \mathrm{Le}^{\mathrm{y}} / \mathrm{Le}^{\mathrm{b}}$ blood group antigens by tumour cells was shown to be a negative prognostic factor in a study conducted by $\mathrm{Mi}$ yake et al. ${ }^{64}$ Resected specimens of 141 NSCLC tumours of pathological stages I-IIIA were investigated and immunoreactivity with MIA15-5 was observed in 91 tumours of various histological types. The five year survival rate was $20.9 \%$ in the MIA-15-5 positive group and $58.6 \%$ in the MIA-15-5 negative group $(p<0.001)$. Cox regression analyses revealed three significant predictors of survival: MIA15-5 status, $\mathrm{N}$ and $\mathrm{T}$ stage. 
Angiogenesis and blood vessel invasion Angiogenesis is an essential step in tumour growth and the metastatic process. ${ }^{65}$ The mechanism that controls angiogenesis under physiological circumstances and in the neoplastic state is complex and involves a number of stimulating and inhibitory factors, ${ }^{66}$ including p53. ${ }^{22}$ Macchiarini et al studied induction of blood vessels ${ }^{67}$ and invasion by tumour cells ${ }^{68}$ in patients with pathological T1N0M0 NSCLC. Angiogenesis was assessed by the number of microvessels as revealed by staining the tumour for factor VIII. The relative risk (RR) for development of metastatic disease increased from $1(6 / 65)$ in patients with low microvessel counts to $2.42(10 / 16, \mathrm{p}<0.0001)$ for those with intermediate microvessel counts and $2 \cdot 0(6 / 6$, $\mathrm{p}<0.0001)$ for those with high microvessel counts. Invasion of such blood vessels by tumour cells was found in 16 of 95 pathological T1N0M0 tumours in their second study, thereby increasing substantially the relative risk of recurrent metastatic disease (RR 25.64, $\mathrm{p}<0.00001$ ). In this mature study (median follow up 8.3 years, five year survival $75 \%$ ) invasion of blood vessels was the only independent significant prognostic factor in multivariate analysis for disease free survival. Vascular invasion of the pulmonary arteries or veins using standard pathological criteria was also shown to be associated with adverse long term survival in patients with T1-2N0M0 NSCLC. ${ }^{34}$ Ten year survival decreased by $50 \%$ $(61 \%$ versus $30 \%)$ in patients with vascular invasion (28 of 271) compared with those without (243 of 271 ) vascular invasion (RR 1.85, $\mathrm{p}<0.05)$.

\section{Micrometastatic disease}

In patients with resectable NSCLC, accurate assessment of lymph node involvement is critical with regard to prognosis given the survival advantage of patients with stage I disease over those with stage II disease. Routine assessment of lymph node involvement relies on examination of haematoxylin and eosin stained sections, but small groups of tumour cells can easily be missed by this method. ${ }^{69-71}$ Immunochemical, cytochemical, and histochemical techniques now allow the detection of single tumour cells in regional lymph nodes. Chen et $a l^{69}$ used a polyclonal antikeratin reagent to assess retrospectively the presence of occult tumour cells in 588 lymph nodes of 60 patients with N0 disease as judged by conventional methods. Positive staining was encountered in $102(17 \%)$ lymph nodes originating from 38 (63\%) patients, of which $20 \%$ were N2. ${ }^{72}$ Occult spread of tumour cells to lymph nodes was seen with all types of histology and grades of differentiation. However, survival of patients with node negative disease as judged by this method was not significantly better than patients with positive lymph nodes or those with overt lymph node metastases (2456 days versus 1977 days versus 927 days; $p>0 \cdot 05$ ). In a prospective study Passlick and coworkers ${ }^{71}$ stained 391 fresh frozen regional lymph nodes from 72 patients with pT1-3NOMO completely resected NSCLC with a monoclonal antibody (Ber-Ep4) that recognised a $34 \mathrm{kD}$ and $49 \mathrm{kD}$ glycoprotein present on epithelial cells. Fifteen nodes $(3.5 \%)$ obtained from 11 patients $(15 \cdot 2 \%)$ contained Ber-Ep4 positive cells. No significant association was found between tumour size or micrometastatic disease in the bone marrow. A profound effect on relapse rate and survival was noted during the median observation period of 26 months (six patients were excluded because of non-cancer related deaths): five of the 10 patients with positive nodes relapsed and three died compared with eight of 56 recurrences and four deaths in the "true" node negative patients. In univariate analysis these figures were highly significant.

In breast and colonic carcinoma occult metastases to the bone marrow have been found to exert a negative influence on survival. ${ }^{73-75}$ Using a monoclonal antibody directed against cytokeratin, Pantel et al $^{70}$ were able to demonstrate individual metastatic tumour cells in the bone marrow of 18 of 82 completely resected NSCLC patients (presumably without distant metastases). After a median of 13 months $66.7 \%$ of patients with bone marrow involvement had relapsed compared with $36.6 \%$ of those without $(p<0.05)$. Interestingly, the number of local recurrences was not different between the two groups $(26 \cdot 7 \%$ versus $22 \%$ ) but the number of patients with distant relapses, especially in the skeleton $(26.7 \%$ versus $2 \cdot 4 \%, \mathrm{p}<0.005)$ was higher in the patients with bone marrow involvement.

\section{Conclusion}

Survival after apparently curative resection of stage I and II NSCLC remains poor, with the exception of those patients with pathological T1N0 tumours. Since patients with resected stage I and II NSCLC often develop late distant metastases, systemic treatment (chemotherapy) seems to be the most logical adjuvant therapy. Traditional methods to assess prognosis in these patients have relied upon stage of disease at presentation and performance status. Randomised clinical trials to compare adjuvant chemotherapy with observation only in which patients were stratified for these prognostic factors have yielded conflicting results. ${ }^{76-78}$

Advances in the understanding of carcinogenesis and tumour progression have now identified other significant prognostic factors. Incorporation of these factors into a risk model for recurrence after resection would help to define a rational treatment strategy for patients with stage I and II NSCLC. Recently developed techniques such as PCR have facilitated the analysis of DNA abnormalities, and the identification of the protein products of mutated genes or overexpression of normal genes with (monoclonal) antibodies permits reliable analysis of these factors in small tissue samples such as biopsy specimens.

However, several issues remain to be resolved before this work can be incorporated into the clinical management of patients with early stage NSCLC. Firstly, although it seems that at least some of these markers are uniformly present 
in a tumour, ${ }^{79}$ for others the problem of biopsy samples and tumour heterogeneity needs to be considered. From the current literature it is not clear whether biopsy specimens do contain all genetic and molecular abnormalities that can be found in tissue blocks. Secondly, almost all the studies so far reported have analysed small groups of patients. Thirdly, the stage of the disease in most older studies was probably underestimated and consequently the clinical outcome of advanced stage NSCLC may have been analysed. Some of the studies cited above included patients with stage IIIA NSCLC, a stage which is not recognised by everyone as "early". Fourthly, because of differences in biomarkers analysed and statistical methods used, comparison between studies is difficult if not impossible. Finally, only a few reports focus on the interrelationship between individual biomarkers.

A number of prospective studies are therefore needed to try to validate the value of these biological factors. The importance of such studies is illustrated by the randomised study of Rosell et $a l^{80}$ who examined the effect of preoperative chemotherapy in patients with stage IIIA NSCLC and found a highly significant $(p<0.001)$ difference in median survival in favour of the chemotherapy treated group (26 versus 8 months). However, the conclusion of this study that preoperative chemotherapy increases survival in these patients has been challenged on the basis that, in the control arm, the prevalence of K-ras mutations was significantly higher $(42 \%$ versus $15 \%, p<0.05)$ than in the chemotherapy treated patients.

Ideally, such studies should include a treatment arm and an observation arm to which patients are randomly allocated on the basis of defined biological markers. The major obstacle for such studies is the fact that, on the present evidence, it is not yet possible to define the risk groups accurately. For example, Strauss et $a l^{81}$ propose to randomise patients with stage I NSCLC according to $T$ status ( $T 1$ versus $T 2$ ). All patients with T2 tumours are to be randomised to resection and observation or postoperative treatment with chemotherapy (cisplatin and vinblastine). A recently started study of the Dutch Lung Cancer Study Group is randomising patients with stage I (except T1N0) and stage II NSCLC to preoperative chemotherapy (cisplatin and teniposide) or immediate resection. In both studies patients will be carefully and prospectively evaluated and a battery of prognostic variables (both clinical and biological) are being measured. Accordingly, a high risk group of patients for recurrent NSCLC after resection may be defined and evaluated. Apart from considering the question as to whether chemotherapy can alter the prognosis of patients with early stage NSCLC, an additional advantage of such studies is the possibility of identifying the subgroups that are most likely to benefit from (neo)adjuvant chemotherapy. Unfortunately, the same biological factors which confer an adverse prognosis after resection are also implicated in resistance to chemotherapy. For instance, inability of cells to undergo apoptosis following chemotherapy is related to loss of $\mathrm{p} 53$ function and Bcl-2 overexpression. ${ }^{218283}$ K-ras mutations have been linked to resistance to platinum compounds and etoposide. ${ }^{8485}$

Alternatively, these biological markers themselves may be the specific targets of future therapy strategies. Retroviral mediated gene therapy, introducing wild type p53 gene, ${ }^{86}$ wild type RB gene, ${ }^{87}$ and anti-sense K-ras ${ }^{88}$ into tumour cells, has been shown to inhibit tumour growth in animal models. Ras function may also be inhibited by targeting the enzyme which incorporates $\mathrm{p} 21^{\text {ras }}$ into the plasma membrane and the use of cytotoxic $\mathrm{T}$ lymphocytes specific for mutant K-ras epitopes. ${ }^{89}$ Modified monoclonal antibodies directed against the extracellular domain of c-ErbB-2 display potent cytotoxic effects in vivo on tumour cells expressing c-ErbB-2. ${ }^{90}$ Inhibitors of carbohydrate processing constitute a novel class of anticancer agents of which the first, the alkaloid swainsonine, has recently been tested in phase I trials. ${ }^{91}$ The specific inhibition of tumour derived angiogenic factors is an attractive therapeutic target which has shown promising results in animal models. ${ }^{92} 93$ Micrometastatic disease may be prevented from further progression by inhibiting specific cell surface receptors ${ }^{94}$ or membrane proteases. ${ }^{95}$

In summary, new prognostic factors based on our knowledge of carcinogenesis and tumour progression have been identified in early stage NSCLC. Prospective clinical trials incorporating (neo)adjuvant chemotherapy need to be initiated to try to validate the clinical value of these biological factors even if improvement in survival is small. The magnitude of the problem which is posed by the current epidemic of lung cancer justifies such an approach.

1 Mountain CF. A new international staging system for lung cancer. Chest 1986;89:225-33.

2 Read RC, Scheafer R, North N, Walls R. Diameter, cell type and survival in stage $I$ non small cell lung cancer. Arch Surg 1988;123:446-9.

3 Pairolero PC, Williams DE, Bergstrahl EJ, Piehler JM Bernatz PE, Payne WS. Postsurgical stage I bronchogenic carcinoma: morbid implications of recurrent disease. Ann Thorac Surg 1984;38:331-6.

4 Martini N, Burt ME, Bains MS, McCormack PM, Rusch VW, Ginsberg RJ. Survival after resection of stage II nonsmall cell lung cancer. Ann Thorac Surg 1992;54:460-6.

5 Sorensen JB. Impact of prognostic factors on endpoints for clinical studies. Proc. IASLC workshop controversies in staging and treatment of locally advanced non small cell lung cancers. Bruges, 1993.

6 Buccheri G, Ferringo D. Prognostic factors in lung cancer: tables and comments. Eur Respir 7 1994;7:1350-64.

7 Miyamoto H, Harada M, Isobe H, Akita HD, Haneda H, Yamaguchi E, et al. Prognostic value of nuclear DNA Yamaguchi $\mathrm{E}$, et al. Prognostic value of nuclear DNA content and expression of the ras oncoge

8 Tirindelli-Danesi D, Teodori L, Mauro F, Modini C, Botti C, Cicconetti F, et al. Prognostic significance of flow cytometry in lung cancer. A 5-year study. Cancer 1987 60:844-51.

9 Zimmerman PV, Bint MH, Hawson GAT, Parsons PG. Ploidy as a prognostic determinant in surgically treated lung cancer. Lancet 1987;ii:530-3.

10 Volm M, Hahn EW, Mattern J, Muller T, Vogt-Moykopf I Weber E. Five-year follow-up study of independent clinical and flow cytometric prognostic factors for the survival of patients with non-small cell lung carcinoma. Cancer Res 1988;48:2923-8.

11 Ten Velde GPM, Schutte B, Vermeulen A, Volovics A, Reynders MMJ, Blijham GH. Flow cytometric analysis of DNA ploidy level in paraffin-embedded tissue of non455-60.

12 Van Bodegom PC, Baak JPA, Stroet-van Galen C, Schipper NW, Wisse-Brekelmans ECM, Vanderschueren RGJRA, et al. The percentage of aneuploid cells is significantly et al. The percentage of aneuploid cells is significantly
correlated with survival in accurately staged patients with 
stage I resected squamous cell lung cancer and long-term follow up. Cancer 1989;63:143-7.

13 Isobe $\mathrm{H}$, Miyamoto $\mathrm{H}$, Shimizu T, Haneda $\mathrm{H}$, Hashimoto $\mathrm{M}$, Inoue $\mathrm{K}$, et al. Prognostic and therapeutic significance of the flow cytometric nuclear DNA content in non-small cell lung cancer. Cancer 1990;65:1391-5.

14 Ogawa J, Tsurumi $\mathrm{T}$, Inoue $\mathrm{H}$, Shohtshu A. Relationship between tumor DNA ploidy and regional lymph node changes in lung cancer. Cancer 1992;69:1688-95.

15 Filderman AE, Silvestri GA, Gatsonis C, Luthringer DJ, Honig J, Flynn SD. Prognostic significance of tumor proliferative fraction and DNA content in stage I non-small cell lung cancer. Am Rev Respir Dis 1992;146:707-10.

15 Harris CC, Hollstein M. Clinical implications of the p53 tumor-suppressor gene. N Engl F Med 1993;329:1318-27.

17 Vogelstein B, Kinzler KW. p53 function and dysfunction. Cell 1992;70:523-6.

18 Levine AJ, Perry ME, Chang A, Silver A, Dittmer D, Wu $M$, et al. The 1993 Walter Hubert Lecture: the role of the p53 tumour-suppressor gene in tumorigenesis. BrF Cancer 1994;69:409-16.

19 Prives C. How loops, b sheets and a helices help us to understand p53. Cell 1994;78:543-6.

20 Friend S. p53: a glimpse at the puppet behind the shadow play. Science 1994;265:334-5.

21 Hartwell LH, Kastan MB. Cell cycle control and cancer. Science 1994;266:1821-8.

22 Dameron K, Volpert O, Tainsky M, Bouck N. Control of angiogenesis in fibroblasts by $\mathrm{p} 53$ regulation of thrombospondin-1. Science 1994;265:1582-5.

23 Greenblatt MS, Bennett WP, Hollstein M, Harris CC Mutations in the p53 tumor suppressor gene: clues to cancer etiology and molecular pathogenesis. Cancer Res 1994;54:4855-78.

24 Walker C, Robertson LJ, Myskow MW, Pendleton N, Dixon GR. p53 expression in normal and dysplastic bronchial epithelium and in lung carcinomas. Br 7 Cancer 1994;70. 297-303.

25 Sozzi G, Miozzo M, Donghi R, Pilotti S, Cariani CT, Pastorino $U$, et al. Deletions of $17 \mathrm{p}$ and $\mathrm{p} 53$ mutations in preneoplastic lesions of the lung. Cancer Res 1992;52: in preneopla

26 Sozzi G, Miozzo M, Pastorino U, Pilotti S, Donghi R, Giarola $M$, et al. Genetic evidence for an independent origin of multiple preneoplastic and neoplastic lung lesions. Cancer Res 1995;55:135-40.

27 Cho Y, Gorina S, Jeffry P, Pavletich NP. Crystal structure of a 553 tumor suppressor-DNA complex: a framework or understanding how mutations inactivate p53. Science 1994;265:353-7.

28 Hall PA, Lane DP. p53 in tumor pathology: can we trust immunohistochemistry?-revisited. F Pathol 1994;172:1-4.

29 Quinlan DC, Davidson AG, Summers CL, Warden HE Doshi HM. Accumulation of $\mathrm{p} 53$ protein correlates with a poor prognosis in human cancer. Cancer Res 1992;52: a poor progr

30 Horio Y, Takahashi T, Kuroishi T, Hibi K, Suyama M, Niimi T, et al. Prognostic significance of p53 mutation and $3 p$ deletions in primary resected non-small cell lung cancer. Cancer Res 1993;53:1-4.

31 Passlick B, Izbicki JR, Riethmuller G, Pantel K. p53 in nonsmall cell lung cancer. $\mathcal{F}$ Natl Cancer Inst 1994;86:801-2.

$32 \mathrm{Xu} \mathrm{HJ}$, Quinlan DC, Davidson AG, Hu SX, Summers CI $\mathrm{Li} \mathrm{J}$, et al. Altered retinoblastoma protein expression and prognosis in early-stage non-small-cell lung carcinoma. $\mathcal{F}$ Natl Cancer Inst 1994;86:695-9.

33 Ebina M, Steinberg S, Mulshine JL, Linnoila RI. Relationship of $\mathrm{p} 53$ overexpression and up-regulation of proliferating cell nuclear antigen with the clinical course of non-small cell lung cancer. Cancer Res 1994;54:2496-503.

34 Harpole DH, Herndon JE, Wolfe WG, Iglehart JD, Mark JR. A prognostic model of recurrence and death in stage I non-small cell lung utilizing presentation, histopathology and oncoprotein expression. Cancer Res 1995;55:51-6.

35 Carbone DP, Mitsudomi T, Rusch V, Nowak JA, Mcintire $\mathrm{D}$, Chiba I, et al. p53 protein overexpression, but not gene mutation, is predictive of significantly shortened survival in resected non-small cell lung cancer (NSCLC) patients. Proc Am Soc Clin Oncol 1994:12:334 (abstract).

36 Chang F, Syrjanen S, Syrjanen K. Implications of the p53 tumor-suppressor gene in clinical oncology. 7 Clin Oncol 1995;13:1009-22

37 Melhem MF, Law JC, El-Ashmawy L, Johnson JTJ, Landreneau RJ, Srivastava $S$, et al. Assessment of sensitivity and specificity of immunohistochemical staining of $\mathrm{p} 53$ in lung and head and neck cancers. Am $\mathcal{F}$ Pathol 1995 146:1170-7

38 Slebos RJC, Lee MH, Plunkett BS, Kessis TD, Williams BO, Jacks T, et al. p53-dependent G1 arrest involves pRBrelated proteins and is disrupted by the human papillomavirus 16 E7 oncoprotein. Proc Natl Acad Sci USA 1994;91:5320-4.

39 Williams BO, Remington L, Albert DM, Mukai S, Bronson RT, Jacks T. Cooperative tumorigenic effects of germline mutations in $\mathrm{Rb}$ and $\mathrm{p} 53$. Nature Genetics 1994;7:480-4.

40 Hall A. The cellular functions of small GTP-binding proteins. Science 1990;249:635-40.

41 Rodenhuis S, Slebos RJC. Clinical significance of ras oncogene activation in human lung cancer. Cancer Res 1992; 52:2665s-9s

42 Slebos RJC, Kibbelaar RE, Dalesio O, Kooistra A, Stam $\mathrm{J}$, Meijer CJLM, et al. K-ras oncogene activation as a prognostic marker in adenocarcinoma of the lung. $N$ Engl f Med 1990;323:561-5.
43 Chang EH, Furth ME, Scolnick EM, Lowry DR. Tumorigenic transformation of mammalian cells induced by a normal human gene homologues to the oncogene of Harvey murine sarcoma virus. Nature 1982;297:479-82.

44 Mills NE, Fishman CL, Rom WN, Dubin N, Jacobson DR. Increased prevalence of K-ras oncogene mutations in lung adenocarcinoma. Cancer Res 1995;55:1444-7.

45 Kern JA, Slebos RJC, Top B, Rodenhuis S, Lager D, Robinson RA, et al. C-erbB-2 expression and codon 12 K-ras mutations both predict shortened survival for patients with pulmonary adenocarcinomas. $\mathcal{f}$ Clin Invest 1994;93:516-20.

46 Sugio K, Ishida T, Yokoyama H, Sugimachi K, Sasazuki T. Ras gene mutations as a prognostic marker in adenocarcinoma of the human lung without lymph node metastasis. Cancer Res 1992;52:2903-6.

47 Rosell R, Li S, Skacel Z, Mate JL, Maestre J, Canela M, et al. Prognostic impact of mutated K-ras gene in surgically resected non-small cell lung cancer patients. Oncogene 1993;8:2407-12.

48 Mitsudomi T, Steinberg SM, Oie HK, Mulshine JL, Phelps $\mathrm{R}$, Viallet $\mathrm{J}$, et al. Ras gene mutations in non-small cell lung cancers are associated with shortened survival irrespective of treatment intent. Cancer Res 1991;51:49995002

49 Harada M, Dosaka-Akita H, Miyamoto H, Kuzumaki N, Kawakami Y. Prognostic significance of the expression of ras oncogene product in non-small cell lung cancer. Cancer 1992;69:72-7.

50 Yu D, Wang SS, Dulski KM, Tsai CM, Nicolson GL, Hung MC. c-erbB-2/neu overexpression enhances metastatic potential of human lung cancer cells by induction of metastasis-associated properties. Cancer Res 1994;54: 3260-6.

51 Kern JA, Schwartz DA, Nordberg JE, Weiner DB, Greene

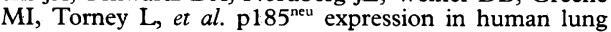
adenocarcinomas predicts shortened survival. Cancer Res 1990;50:5184-91.

52 Schneider PM, Hung MC, Chiocca SM, Manning J, Zhao $\mathrm{X}$, Fang $\mathrm{K}$, et al. Differential expression of the c-erbB-2 gene in human small-cell and non-small cell lung cancer. Cancer Res 1989;49:4968-71.

53 Weiner DB, Nordberg J, Robinson R, Nowell PC, Gazdar $\mathrm{AF}, \mathrm{Greene} \mathrm{MI}$, et al. Expression of the neu gene-encoded protein (p185 18 un in human non-small cell carcinomas of the lung. Cancer Res 1990;50:421-5.

54 Tateishi M, Ishida T, Mitsudomi T, Kaneko S, Sugimachi $K$. Prognostic value of c-erbB-2 protein expression in human lung adenocarcinoma and squamous cell carcinoma. Eur f Cancer 1991;27:1372-5

55 Hibi K, Takahashi T, Yamakawa K, Ueda R, Sekido Y, Ariyoshi Y, et al. Three distinct regions involved in $3 \mathrm{p}$

deletion in human lung cancer. Oncogene 1992;7:445-9.
56 Reed JC. Bcl-2 and the regulation of programmed cell death. 7 Cell Biol 1994;124:1-6.

57 Pezzella F, Turley H, Kuzu I, Tungekar MF, Dunnill MS, Pierce CB, et al. bcl-2 Protein in non-small-cell lung carcinoma. N Engl f Med 1993;329:690-4.

58. Walker C, Robertson L, Myskow M, Dixon G. Expression of the BCL-2 protein in normal and dysplastic bronchial epithelium and in lung carcinomas. Br 7 Cancer 1995;72. 164-9.

59 Damjanov I. Biology of disease: Lectin cytochemistry and histochemistry. Lab Invest 1987;57:5-20.

60 Hakomori S. Aberrant glycocylation in tumors and tumor associated carbohydrate antigens. Adv Cancer Res 1989; 52:257-331.

61 Dennis JW, Laferte S, Waghorne C, Breitman ML, Kerbe RS. B1-6 branching of asn-linked oligosaccharides is directly associated with metastasis. Science 1987;236:582-5.

62 Miyake M, Hakomori SI. A specific cell surface glycoconjugate controlling cell motility: evidence by functional antibodies that inhibit cell motility and tumor metastasis. Biochemistry 1991;30:3328-34.

63 Lee JS, Ro YR, Sahin AA, Hong WK, Brown BW, Mountain $\mathrm{CF}$, et al. Expression of blood group antigen $\mathrm{A}$ : a favourable prognostic factor in non-small cell lung cancer. $N$ Engl $\mathcal{F}$ Med 1991:324:1084-90.

64 Miyake M, Toshihiko T, Hitomi S, Hakamori SI. Correlation of expression of $\mathrm{H} / \mathrm{Le}^{\mathrm{y}} / \mathrm{le}^{\mathrm{b}}$ antigens with survival in patients with carcinoma of the lung. $N$ Engl $\mathcal{F ~ M e d}$ 1992;327:14-8

65 Scott PAE, Harris AL. Current approaches to targeting cancer using antiangiogenesis therapies. Cancer Treatment Rev 1994;20:393-412

66 Fidler IJ, Ellis LM. The implications of angiogenesis for the biology and therapy of cancer metastasis. Cell 1994;79: 185-8.

67 Macchiarini P, Fontanini G, Hardin MJ, Squartini F, Angeletti CA. Relation of neovascularisation to metastasis of non-small-cell lung cancer. Lancet 1992;340:145-6.

68 Macchiarini P, Fontanini G, Hardin MJ, Chuanchieh H Bigini $\mathrm{D}$, Vignati $\mathrm{S}$, et al. Blood vessel invasion by tumor
cells predicts recurrence in completely resected T1NOMO cells predicts recurrence in completely resected T1N0MO non-small

69 Chen ZL, Perez S, Holmes EC, Wang HJ, Coulson WF, Wen DR, et al. Frequency and distribution of occult micrometastases in lymph nodes of patients with nonsmall-cell lung carcinoma. $\mathcal{F}$ Natl Cancer Inst 1993;85 493-8.

70 Pantel K, Izbicki JR, Angstwurm M, Braun S, Passlick B, Karg $\mathrm{O}$, et al. Immunocytological detection of bone marrow metastases in operable non-small cell lung cancer. Cancer Res 1993;53:1027-31. 
71 Passlick B, Izbicki JR, Kubuschok B, Nathrath W, Thetter $\mathrm{O}$, Pichlmeier U, et al. Immunohistochemical assessment of individual tumor cells in lymph nodes of patients with non-small-cell lung cancer. F Clin Oncol 1994;12:1827-32.

72 Mountain CF, Lukeman JM, Hammer SP, Chamberlain $\mathrm{DW}$, Coulson WF, Page DC, et al. Lung classification: the relationship of disease extent and cell type to survival in clinical trials population. $\mathcal{F}$ Surg Oncol 1987;35:147-56.

73 Lindemann F, Schlimok G, Dirschedl P, Witte J, Riethmüler G. Prognostic significance of micrometastic tumor cells in bone marrow of colorectal cancer patients. Lancet 1992; 340:685-9.

74 Harbeck N, Untch M, Pache L, Eiermann W. Tumor cell detection in the bone marrow of breast cancer patients at primary therapy: results of a 3-year median follow-up. $B$ 7 Cancer 1994;69:566-71.

75 Menard S, Squicciarini P, Luini A, Sacchinni V, Rovini D, Tagliabue E, et al. Immunodetection of bone marrow micrometastasis in breast carcinoma patients and its correlation with primary tumor prognostic features. $\mathrm{Br} F$ Cancer 1994;69:126-9.

76 Holmes EC, Gail M, Lung Cancer Study Group. Surgical adjuvant therapy for stage II and stage III adenocarcinoma and large cell undifferentiated carcinoma. 7 Clin Oncol and large cell

77 Feld R, Rubinstein L, Thomas PA, and the Lung Cancer Study Group. Adjuvant chemotherapy with cyclophosphamide, doxorubicin, and cisplatin in patients with completely resected stage I non-small-cell lung cancer. $\mathcal{f}$ Natl Cancer Inst 1993;85:299-306.

78 Niiranen A, Niitamo-Korhonen S, Kouri M, Assendelft A, Mattson K, Pyrhönen S. Adjuvant chemotherapy after radical surgery for non-small-cell lung cancer: a randomized study. F Clin Oncol 1992;10:1927-32.

$79 \mathrm{Li} \mathrm{ZH}$, Zheng J, Weiss LM, Shibata D. c-K-ras and p53 mutations occur very early in adenocarcinoma of the lung. Am 7 Pathol 1994;144:303-9.

80 Rosell R, Gomez-Codina J, Camps C, Maestre J, Padille J, Canto A, et al. A randomized trial comparing preoperative chemotherapy plus surgery with surgery alone in patients with non-small-cell lung cancer. $N$ Engl $\mathcal{F}$ Med 1994;330 153-8.

81 Strauss GM, Kwiatkowski DJ, Harpole DH, Lynch TJ, Skarin AT, Sugarbaker DJ. Molecular and pathological markers in stage I non-small-cell carcinoma of the lung. Clin Oncol 1995;13:1265-79.

82 Lowe SW, Ruley HE, Jacks T, Housman DE p53-Dependent apoptosis modulates the cytotoxicity of anticancer pendent apoptosis modulates th

83 Fisher DE. Apoptosis in cancer therapy: crossing the threshold. Cell 1994;78:539-42.

84 Sklar MD. Increased resistance to cis-diammine-dichloroplatinum (II) in NIH $3 \mathrm{~T} 3$ cells transformed by ras oncogenes.

85 Rosell R, Li S, Anton A, Moreno I, Martinez E, Vadell C, et al. Prognostic value of K-ras 12 genotypes in patients with advanced non-small cell lung cancer receiving carboplatin with either intravenous or chronic oral dose etoposide. Int f Oncol 1994;5:195-8.

86 Fujiwara T, Cai DW, Georges RN, Mukhopadhyay T, Grimm EA, Roth JA. Therapeutic effect of a retrovira wild-type p53 expression vector in an orthotopic lung cancer model. I Natl Cancer Inst 1994;86:1458-62.

87 Cordon-Cardo $C$. Mutation of cell cycle regulators. Biological and clinical implications for human neoplasia. $A m$ f Pathol 1995;147:545-60.

88 Georges RN, Mukhopadhyay T, Zhang Y, Yen Y, Roth JA Prevention of orthotopic human lung cancer growth by intratracheal instillation of a retroviral anti-sense K-ras intratracheal instillation of a retroviral ar

89 Kanters SDJM, Lammers JWJ, Voest EE. Molecular and biological factors in the prognosis of non-small cell lung biological factors in the prognosis of
cancer. Eur Respir f 1995;8:1389-97.

90 Hynes NE, Beerli R, Graus-Porta D, Schmidt M, Groner Hynes NE, Beerli R, Graus-Porta D, Schmidt M, Groner
B, Wels W. ErbB-2 and EGF receptor as targets for breast cancer therapy. Proc Am Ass Cancer Res 1995;36:690-1.

91 Goss PE, Baker MA, Carver JP, Dennis JE. Inhibitors of carbohydrate processing: a new class of anticancer agents. Clin Cancer Res 1995;1:935-44

92 Olson KA, Fett JW, French TC, Key ME, Vallee BL Angiogenin antagonists prevent tumor growth in vivo. Proc Natl Acad Sci USA 1995;92:442-6.

93 Baillie CT, Winslet MC, Bradley NJ. Tumour vasculature - a potential therapeutic target. Br f Cancer 1995;72: 257-67.

94 Crowley CW, Cohen RL, Lucas BK, et al. Prevention of metastasis by inhibition of the urokinase receptor. Proc Natl Acad Sci USA 1993;90:5021-5.

95 Vassalli JD, Pepper MS. Membrane proteases in focus. Nature 1994;370:14-5. 